\title{
ANALISIS FAKTOR-FAKTOR YANG MEMPENGARUHI AUDITOR SWITCHING PADA PERUSAHAAN YANG TERDAFTAR DI JAKARTA ISLAMIX INDEX TAHUN 2013-2017
}

\author{
Kartika Hendra Titisari ${ }^{1}$, Suhendro ${ }^{2}$, Rohmat Hidayat ${ }^{3}$ \\ ${ }^{1,2,3}$ Fakultas Ekonomi Jurusan Manajemen Universitas Islam Batik Surakarta \\ rohmathidayat.0595@gmail.com
}

\begin{abstract}
Abstrak
Penelitian ini bertujuan untuk menguji beberapa faktor yang dapat mempunyai pengaruh terhadap Auditor switching. Komponen - komponen yang biasanya mempunyai pengaruh adalah pergantian manajemen, opini audit, financial distress, presentase ROA, patokan KAP, dan patokan perusahaan klien. Dalam penelitian ini populasinya adalah semua perusahaan manufakur yang telah terdaftar di JII periode 2011-2017. Penentuan sampel dilakukan dengan sistem purpose sampling, sehingga didapatkan perusahaan sampel sebanyak 80. Alat analisis menggunakan regresi logistik sesuai dengan kriteria tersebut. Dari penelitian ini didapatkan hasil bahwa auditor switching tidak dipengaruhi oleh adanya pergantian manajemen. Auditor switching tidak dipengaruhi oleh opini audit. Auditor switching dipengaruhi oleh prosentase ROA. Auditor switching tidak dipengaruhi ukuran KAP dan wald. Auditor switching tidak dipengaruhi perusahaan klien.
\end{abstract}

Kata Kkunci : Auditor Switching, Jakarta Islamic Index,

\section{PENDAHULUAN}

Auditor switching didefinisikan sebagai pergantian Instansi Akuntan Publik yang dilaksanakan perusahaan sebab ketentuan pemerintah ataupun sebab ketentuan di dalam perusahaan tunggal. Auditor switching dilakukan sebab wajib dilaksanakan setara beserta prosedur yang berlangsung di dalam perusahaan. Pengantian auditor punya tuntutan mempertahankan indepedensi auditor supaya obyektif setara dengan tuntutan tugasnya.

Instansi Akuntan Publik yang berlegalitas secara umum menyelenggarakan integritas audit serta supremasi yang unggul di dalam kontinen perbisnisan. Dari segi diviato (2011), Institusi Akuntan Publik punya dampak substansial, sinkron dan afirmatif pada auditor switching, berbeda halnya pada penjelasan oleh Sianipar (2015) menyingkapkan jika variabel parameter KAP tak mempengaruhi auditor switching. Naik nya bea keagenan dikarenakan oleh jumlah kerumitan perusahaan.

Variabel fee audit, pedoman KAP, penggantian manajemen, perusahaan yang limitasi keuangan, saran akuntan serta presentase ROA yang menemui rekonsiliasi dari dampak ulasan di sini mengartikan free audit serta tolok ukur KAP berimbas dalam perusahaan yang melaksanakan auditor switching. Ulasan di sini punya ukuran memperoleh keterangan keterangan empiris menyangkut konsekuensi, opini audit, tolok ukur KAP, yang bermanfaat di dalam perusahaan menetapkan ketentuan auditoring. Jadi bisa diharapkan atas ulasan ini didefinisikan sebagai (1) referensi di dalam mengerjakan auditor switching untuk yang menyandang karier akuntan umum; (2) setaraf pengertian dan wawasan mengenai auditor switching; (3) setaraf referensi pengerjaan regulasi dalam menjalankan auditor switching yang terkait pada UU PT serta UU PM; (4) serupa material dan referensi di dalam melaksanakan auditor switching. 


\section{TINJAUAN PUSTAKA}

Menafsirkan mengenai sejumlah unsur yang punya dampak terhadap perseroan di Indonesia yang melaksanakan auditor switching antara lain pergantian manajemen, opini audit, financiual distress, penurunan presentase ROA standar KAP dan standar perusahaan klien.

Pergantian tata ialah pergantian pimpinan perseroan yang bisa dikarenakan oleh ketentuan rapat umum pemegang saham maupun pimpinan habis oleh keingin hati seorang diri. Rekonsiliasi kebijakan suatu perubahan barangkali bakal berlangsung, sebab ada nya manajemen yang terkini. Saran audit merupakan putusan nama lain gagasan yang diberikan sebab pengaudit dan putusan nama lain pertimbangan diberikan supaya perseroan mengetahui mengenai kewajaran manifesto keuangan. Financial disstres adalah suatu keadaan perusahaan yang menemui kesusahan di dalam ekonomi perusahaan.

Perkiraan return of asset (ROA) berpotensi menggambarkan level profitabilitas perusahaan. Profitabilitas bisa sebagai satu diantara ukuran kemampuan laporan keuangan sebuah perusahaan yang mampu menjabarkan status klien dengan sepenuhnya. rekonsiliasi presentase ROA Return On Asset termasuk diantara proksi atas nama baik klien/ client reputasion. Tolok ukur TUDUNG di dalam penelitian tersebut termasuk besar kecilnya KAP yang dipilah sebagai dua grup antara lain KAP yang berafiliasi pada Big 4 hewan KAP yang bukan berafiliasi pada BIG 4. KAP buntal Punya pengaruh semakin bagus di dalam melaksanakan audit dibanding KAP ringkas, maka itu sanggup menciptakan bobot audit yang semakin unggul. Tolok ukur perseroan klien termasuk suatu standar yang menjelaskan besar kecilnya perusahaan yang terkait dengan financial perusahaan.

\section{METODE PENELITIAN}

Penelitian ini dilakukan dengan metode hipotesis kuantitatif. Sedangkan cara pengambilan sampel harus sesuai dengan karakteristik dengan kriteria yang sudah ditentukan. Data sekunder yang dipakai harus sesuai dengan perusahaan yang sudah terdaftar dalam Jakarta Islamic Index dengan acuan melihat laporan perusahaan setiap tahunnya. Sehingga dapat diambil dkomumentasi dari laporan itu.

Penelitian ini menggunakan auditor switching (variabel dummy) sebagai variabel dependennya. Jika KAP berganti maka akan teridentifikasikan dengan nilai 1 , namun jika setiap tahun menggunakan KAP yang tidak sama maka akan ditunjukkan dengan angka 0 .

Karena variabelnya kemungkinan dapat berubah maka penelitian ini menggunakan Variabel Independen, antara lain adalah Ukuran Perusahaan Klien, Prosentase ROA, Opini Audit, Financial Distress, Pergantian Manajemen dan Ukuran KAP.

\section{HASIL DAN PEMBAHASAN}

4.1 Hasil

1) Analisis Deskriptif

Tabel 1 Analisis Statistik Diskriptif Seluruh Sampel

\begin{tabular}{lrrrrr}
\hline & N & Minimum & Maximum & Mean & $\begin{array}{r}\text { Std. } \\
\text { Deviation }\end{array}$ \\
\hline SWITCH & 80 & .00 & 1.00 & .0500 & .21932 \\
PM & 80 & .00 & 1.00 & .1625 & .37124 \\
OA & 80 & .00 & 1.00 & .8000 & .40252 \\
DER & 80 & .00 & 1.00 & .0125 & .11180 \\
ROA & 80 & -289.00 & 328.09 & -7.0313 & 69.86884 \\
UKAP & 80 & .00 & 1.00 & .9375 & .24359 \\
UKLN & 80 & 11.54 & 30.84 & 18.6438 & 5.06130
\end{tabular}




$$
\begin{aligned}
& \begin{array}{l}
\text { Valid N } \\
\text { (listwise) }
\end{array} \\
& \text { Sumber : Data sekunder diolah, } 2018
\end{aligned}
$$

Variabel Pergantian Manajemen (PM) memiliki ukuran rata-rata sebesar 0,1625 mempunyai nilai devisiasi 0,37124 , jadi pergantian manajemen bisa dilakukan karena pelaksanaan regulasi berkaitan kepada pembatasan jasa audit.

2) Uji Asumsi Klasik

a) Uji Normalitas Data

Tabel 2 Hasil Uji Normalitas

One-Sample Kolmogorov-Smirnov Test

\begin{tabular}{|ll|r|}
\hline & & SQ_PM \\
\hline $\mathrm{N}$ & & 80 \\
Normal Parameters $^{\mathrm{a}}$ & Mean & .1625 \\
& Std. Deviation & .37124 \\
& Absolute & .507 \\
Most Extreme & Positive & .507 \\
Differences & Negative & -.331 \\
& & 4.532 \\
Kolmogorov-Smirnov Z & & .000 \\
Asymp. Sig. (2-tailed) & & \\
\hline
\end{tabular}

a. Distribusi test normal.

Tabel diatas menunjukkan Hasil Uji Normalitas ketidaknormalan dari residual data distribusi karena nilai Asymp. Sig. ( 2 tailed ) >0,05 yaitu sebesar 0,00. Sehingga dapat ditarik kesimpulan model penelitian diatas mempunyai nilai residual yang terdistribusi tidak normal.

b) Uji Multikolonieritas

Tabel 3 Hasil Uji Multikolinieritas

\begin{tabular}{lccc}
\hline & Tolerance & VIF & Keterangan \\
\hline SWICH_Y PM & .789 & 1.267 & Tidak terjadi multikolinieritas \\
OA & .973 & 1.027 & Tidak terjadi multikolinieritas \\
DER & .861 & 1.161 & Tidak terjadi multikolinieritas \\
ROA & .925 & 1.081 & Tidak terjadi multikolinieritas \\
UKAP & .736 & 1.360 & Tidak terjadi multikolinieritas \\
UKLN & .842 & 1.188 & Tidak terjadi multikolinieritas \\
\hline
\end{tabular}

Sumber: data diolah melalui SPSS versi 2016

Dari tabel diatas mempunyai arti tidak adanya variabel bebas yang mempunyai angka toleran kurang dari 0,1 begitu juga angka VIF dari setiap variabel tak ada satupun yang mempunyai angka lebih dari 10 sehingga dapat ditarik kesimpulan bahwa variabel bebas tidak mempunyai korelasi yang sempurna, jadi tidak mempunyai masalah yang multikolinieritas. 
c) Uji Autokorelasi

Tabel 4 Hasil Uji Autokorelasi

\begin{tabular}{ccccc}
\hline DW & Dl & Du & 4-du & Keterangan \\
\hline 0.529 & 1.5496 & 1.8031 & 2.1969 & $\begin{array}{c}\text { Tidak ada autokorelasi } \\
\text { positif }\end{array}$ \\
\hline
\end{tabular}

Sumber: data diolah 2017

Dari tabel data diatas yang dibuat dengan menggunakan computer SPSS 16.0 for windows diperoleh nilai DW (0.529). hasil ini jika dibandingkan dengan nilai yang di dapat pada table DW yang menggunakan derajat kepercayaan 5\%, jumlah $\mathrm{n}$ penelitian 100 yang di dapat dari 20 perusahaan sampel dalam 5 peridoe dan jumlah variable independen 6, didapatkan DL 1.5496 dan nilai DU 1.8031. dari hasil tersebut nilai DW diantara 0 dan DU (0 $<0.529<1.5496)$ maka didapatkan kesimpulan bahwa ternyata tidak ada autokorelasi positif pada data penelitian.

d) Uji Heterokedastisitas

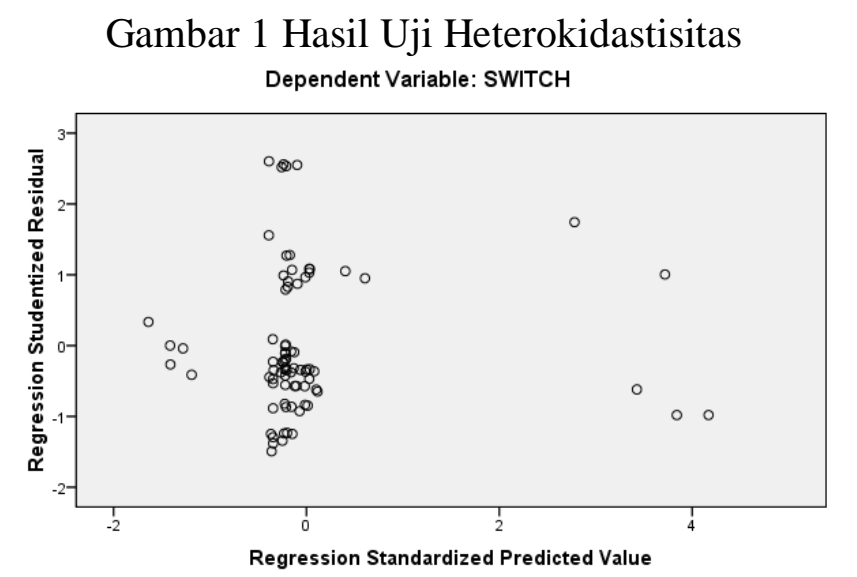

Sumber: data diolah melalui SPSS versi 2016

Dari tabel grafik diatas dapat ditarik sebuah kesimpulan tidak adanya gejala heterokidatisitas, dimana tidak terdapatnya kejelasan sebuah pola pada grafik dan posisi titik-titik yang tersebar diatas dan dibawah 0 begitu juga sumbu $Y$.

e) Hasil Uji Regresi Logistik

Tabel 5 Hasil Uji Regresi Linier Berganda

\begin{tabular}{|c|c|c|c|c|}
\hline Variabel & $\begin{array}{l}\text { Unstandardized } \\
\text { Coefficients B }\end{array}$ & $\mathrm{t}$ & $\mathrm{F}$ & Signifikansi \\
\hline (Constant) & 26.352 & 11.027 & 2.453 & .000 \\
\hline PM & -.243 & -.087 & & .931 \\
\hline OA & .518 & .351 & & .727 \\
\hline DER & .261 & .181 & & .857 \\
\hline ROA & -2.657 & -1.037 & & .303 \\
\hline UKAP & .006 & -.658 & & .513 \\
\hline UKLN & -8.425 & -3.485 & & .001 \\
\hline
\end{tabular}




\begin{tabular}{lc}
\hline $\mathrm{N}$ & 100 \\
\hline R Square & 0.491 \\
Adjusted R Square & 0.470 \\
\hline
\end{tabular}

Sumber : Data sekunder diolah, 2017

Model regresi diatas dapat disimpulkan bahwa interprestasinya adalah:

(1) Hasil nilai wald pergantian manajemen (PM) bernilai negatif yaitu 0,931. Maka nilai dari perusahaan yang belum melakukan auditor switching lebih kecil dibandingkan dengan yang sudah melakukan auditor switching dalam perusahaannya.

(2) Hasil nilai wald opini audit (OA) bernilai positif yaitu 0,727 . Hal ini dapat disimpukan bahwa perusahaan yang telah melakukan auditor switching opini auditnya semakin wajar daripada perusahaan yang belum melakukan auditor switching.

(3) Hasil nilai wald financial distress (DER) bernilai positif yaitu 0,857 . Hal ini menyatakan perusahaan yang sudah menjalankan auditor switching maka financial distress akan semakin bertambah bila disejajarkan dengan perusahaan yang tidak melaksanakan auditor switching.

(4) Hasil nilai wald penurunan persentase ROA (ROA) bernilai negatife yaitu 0,303. Hal ini mempunyai maksud setiap perusahaan yang melaksanakan auditor switching prosentase ROA akan semakin rendah daripada perusahaan yang belum melakukan auditor switching.

(5) Hasil nilai wald ukuran KAP (UKAP) bernilai positif yaitu 0,513. Hal ini menyatakan bahwa perusahaan yang melaksanakan auditor switching maka opini akan semakin meningkat jika diperbandingkan dengan perusahaan yang tidak melaksanakan auditor switching.

(6) Hasil nilai wald ukuran perusahaan klien (UKLN) bernilai negatife yaitu 0,001. Hal ini menunjukkan bahwa setiap perusahaan telah melaksanakan auditor switching maka ukuran perusahaan klien akan semakin meningkat daripada perusahaan yang tidak melakukan sistem auditor switching.

f) Uji Hipotesis

(1) $\mathrm{Hl}$ : Berganti manajemen mempunyai pengaruh dengan auditor switching. Berganti manajemen memiliki nilai koefisien -243 dengan tingkat signifikan 0,931 lebih besar dari 0,05, sehingga membuat $\mathrm{H} 1$ tidak dapat diterima. Maka pergantian manajemen tidak mempunyai sebuah pengaruh auditor switching.

(2) H2: auditor switching dipengaruhi oleh opini audit.

Opini audit mempunyai koefisien dengan nilai 0,518 tingkat signifikansi ( $p$-value) sebesar 0,727 lebih besar dari 0,05 , maka $\mathrm{H} 2$ tidak dapat diterima, sehingga auditor switching tidak dipengaruhi oleh opini audit.

(3) H3: financial distress mempunyai pengaruh pada auditor switching. Financial distress bernilai koefisien 0,261 tingkat signifikansi sebesar 0,857 lebih dari 0,05, maka H3 tidak dapat diterima. Jadi auditor switching tidak dipengaruhi oleh financial distress.

(4) H4: Penurunan persentase ROA mempunyai pengaruh pada auditor switching.

Prosentase ROA bernilai koefisien -2,657 dengan signifikansi senilai 0,303 lebih besar dari 0,05, maka H4 tidak dapat diterima. Sehingga auditor switching tidak dipengaruhi oleh persentase ROA.

(5) H5: Ukuran KAP mempunyai pengaruh pada auditor switching.

Ukuran KAP bernilai koefisien 0.006 tingkat signifikansi 0,513 lebih besar dari 0,05, maka H5 tidak dapat diterima. Sehingga auditor switching tidak dipegaruhi oleh ukuran KAP. 
(6) H6: Ukuran perusahaan klien mempunyai pengaruh pada auditor switching.

Ukuran perusahaan klien bernilai koefisien -8.425 tingkat signifikansi 0,001 lebih besar dari 0,05, maka H2 dapat diterima. Sehingga auditor switching dipengaruhi oleh perusahaan klien.

\subsection{Pembahasan}

1) Akibat Dari Adanya Pergantian Manajemen Dengan Auditor Switching

Faktor pergantian manajemen menyatakan koefisien regresi dengan angka -243 mempunyai signifikansi 0,931 lebih besar dari $\alpha$ (5\%). Sehingga kesimpulannya adalah pergantian manajemen tidak dapat mempunyai pengaruh pada Auditor switching, disebabkan oleh perubahan CEO tidak harus menyertakan perubahan kebijakan perusahaan, karena dari itu perusahaan tetap melakukan pengaktifan auditor yang lama.

2) Pengaruh Opini Audit Terhadap Auditor Switching

Faktor Opini audit (OA) pada koefisien regresi senilai 0.518 memiliki nilai positif bersignifikansi sebesar 0,727 dan lebih tinggi nilainya dari $\alpha(5 \%)$, maka dapat disimpulkan bahwa auditor switching tidak dipengaruhi oleh opini audit, penyebabnya adalah perusahaan yang memanfaatkan jasa empat besar KAP kebanyakan menggunakan KAP yang sama saat menerima opini yang tidak memenuhi syarat. Adanya perubahan KAP dari empat besar ke yang bukan empat besar .

3) Dampak Financial Distress pada Auditor Switching

Faktor Finansial Distress (DER) memperlihatkan angka 0.261(+) mempunyai substansi 0,857 lebih besar daripada $\alpha(5 \%)$. Sehingga dapat disimpulkan auditor swicthing tidak dipengaruhi oleh financial disstress yang disebabkan debt to equity sangat tinggi sehingga KAP tidak perlu untuk diganti.

4) Dampak ROA yang prosentasenya menurun kepada Auditor Switching

Faktor ROA yang prosentasenya menurun $-2,657$ (-) yang tingkat substansinya 0,303 lebih tinggi dari $\alpha(5 \%)$. Maka kesimpulannya adalah ROA tidak mempunyai pengaruh pada Auditor switching. Jadi dapat ditarik kesimpulan bahwa penurunan prosentase ROA (ROA) mempunyai pengaruh pada Auditor Switching. Saat naiknya prosentasi ROA dan masih bagusnya perusahaan sehingga KAP tidak perlu untuk diadakan pergantian. Rendahnya ROA perusahaan lebih dominan untuk berganti auditor sebab adanya nkinerja yang menurun dan akan berpengaruh pada prospek bisnisnya, sehingga saat penurunan finansial perusahaan, auditor akan diganti sehingga diharapkan dapat disembunyikannya atau dimanipulasi kondisi perusahaan.

5) Dampak Patokan KAP Terhadap Auditor Switching

Faktor patokan KAP berkoefisien regresi 0,006 (+) bersignifikansi 0,513> $\alpha(5 \%)$. Kesimpulannya adalah patokan KAP tidak mempunyai pengaruh pada Auditor switching, karena untuk memajukan reputasi perusahaan dan mutu laporan keuangan didepan pengguna laporan keuangan diperlukan pemilihan KAP yang bermutu baik.

6) Dampak Patokan Perusahaan Klien pada Auditor Switching

Faktor patokan perusahaan klien berkoefisiensi $-8,425$ (-) dengan signifikan nilai $0,001<$ $\alpha(5 \%)$. Sehingga disimpulkan patokan perusahaan klien mempunyai pengaruh pada Auditor switching. 


\section{KESIMPULAN}

1) Faktor pergantian manajemen tidak mempunyai pengaruh pada auditor switching yang dibuktikan lebih besarnya substansial jika dibandingkan dengan tingkat substansial sebesar 0,931>0,05, maka ditolaknya H1 dalam penelitian ini.

2) Fakator opini audit tak punya pengaruh pada auditor switching. Dibuktikan lebih besarnya angka signifikan jika dibandingkan dengan tingkat substansial senilai 0,727 >0,05 maka ditolaknya $\mathrm{H} 2$ dalam penelitian ini.

3) Auditor Switching tidak dipengaruhi oleh faktor kesulitan keuangan karena nilai substansial lebih besar jika dibandingkan oleh tingkat signifikansi senilai $0,857>0,05$ maka ditolaknya $\mathrm{H} 3$ di dalam penelitian ini.

4) Faktor penurunan prosentase ROA mempunyai pengaruh pada auditor switching. Maka dapat dinyatakan sebuah bukti melalui adanya tingkat signifikansi yang kecil yaitu sebesar $0,303<0,05$, maka ditolaknya $\mathrm{H} 4$ didalam penelitian ini.

5) Faktor patokan KAP tak mempunyai sebuah pengaruh pada auditor switching. Hal ini dapat diberikan bukti yaitu angka signifikan yang tinggi dengan tingkat signifikansi 0,513 $>0,05$ dan wald 0,031, maka di dalam penelitian ini H5 tidak bisa diterima.

6) Faktor patokan perusahaan klien tak punya pengaruh terhadap auditor switching, karena besarnya nilai signifikansi dari tingkatan signifikansi senilai 0,001 >0,05, maka di dalam penelitian ini $\mathrm{H} 3$ dapat diterima

\section{DAFTAR PUSTAKA}

Astuti, Ni Luh Putu Paramita Novi dan I Wayan Ramantha. 2014. "Pengaruh Audit Fee, Opini Going Concern, Financial Distress dan Ukuran Perusahaan Pada Pergantian Auditor". E-jurnal Akuntansi Universitas Udayana. ISSN: 2302-8556

Buchari, Chana. dan Marita. 2014. "Pengaruh Ukuran KAP, Opini Audit, Pertumbuhan Perusahaan Klien, Pergantian Manajemen dan Ukuran Perusahaan Klien terhadap Pergantian Auditor”. Indonesia Accounting Research Journal, Vol. 2, No. 2.

Chadegani, dkk. 2011. "The Determinant Factors of Auditor Switch among Companies Listed on Tehran Stock Exchange". International Research Journal of Finance and Economics.

Damayanti, S. dan M. Sudarma. 2008. "Faktor-Faktor yang Mempengaruhi Perusahaan Berpindah Kantor Akuntan Publik". Simposium Nasional Akuntansi XI, Pontianak, hal. 1-13.

Divianto. 2011. "Faktor-faktor yang Mempengaruhi Perusahaan dalam Melakukan Auditor Switch (Studi Kasus: Perusahaan Manufaktur di BEI)". Jurnal Ekonomi dan Informasi Akuntansi. Volume 1 Nomor 2.

Ghozali, Imam. 2011. Aplikasi Analisis Multivariate Dengan Program SPSS 19. Semarang: ISBN UNDIP.

Halim, Abdul dan Totok Budi Santoso. 2004. Auditing 2. Yogyakarta: UPP AMP YKPN.

Harvianto, Bayu Putra. 2015. "Analisis Faktor-faktor yang Mempengaruhi Pergantian Kantor Akuntan Publik (Auditor Switching)”. Jom FEKOM. Volume 2 Nomor 2. 
Jensen, M.C. and Meckling, W.H., 1976. The Theory Of The Firm: Managerial Behaviour, Agency Cost And Ownership Structures. Journal Of Financial Economics, Vol.3. pp: 305-360.

Juliantari, Ni Wayan Ari dan Ni Ketut Rasmini. 2013. "Auditor switching dan Faktor-faktor yang Mempengaruhinya". E-Jurnal Akuntansi Universitas Udayana. ISSN: 23028556.

Mardiyah, A.A. 2002. "Pengaruh Faktor Klien dan Faktor Auditor terhadap Auditor Changes: Sebuah Pendekatan dengan Model Kontinjensi RPA (Recursive Model Algorithm)". Simposium Nasional Akuntansi V, Semarang, hal. 425-445.

Menteri Keuangan. 2002. Keputusan Menteri Keuangan Nomor: 423/KMK.06/2002 Tentang Vasa Akuntan Publik", Jakarta.

Menteri Keuangan. 2003. Keputusan Menteri Keuangan Nomor: 359/KMK.062003 Tentang Vasa Akuntan Publik" dan Perubahan atas Keputusan Menteri Keuangan Nomor: 423/KMK.06.2002, Jakarta.

Menteri Keuangan. 2008. Peraturan Menteri Keuangan Nomor 17/PMK.01 /2008 Tentang “Jasa Akuntan Publik”, Jakarta.

Messier, William.F, Steven M. Glover dan Douglas F. Prawitt. 2005. "Jasa Audit \& Assurance: Pendekatan Sistematis”. Terjemahan oleh Nuri Hinduan. Jakarta: Salemba Empat.

Mulyadi. 2009. “Auditing”. Jakarta: Salemba Empat.

Nasser, et.al. 2006. "Auditor-Client Relationship: The Case of Audit tenure and Auditor Switching in Malaysia”. Managerial Auditing Journal, Vol. 21, No. 7, pp. 724-737.

Pawitri, Ni Made Puspa dan Ketut Yadnyana. 2015. "Pengaruh Audit Delay, Opini Audit, Reputasi Auditor dan Pergantian Manajemen pada Voluntary Auditor Switching". Ejurnal Akuntansi Universitas Udayana. ISSN: 2302-8578.

Pratitis, Yanwar Titi. 2012. "Auditor Switching: Analisis Berdasarkan Ukuran KAP, Ukuran Klien dan Financial Distress". Accounting Analysis Journal, Vol. 1, No. 1.

Pusat Pembinaan Profesi Keuangan Sekretariat Jendral-Kementrian Keuangan. 2015. "Pendapatan The Big Four Masih Tinggi" (online), http://pppk.kemenkeu.go. id/News/Details/18, diakses 23 September 2016.

Putra, I Wayan Deva Widia. 2014. "Pengaruh Financial Distress, Rentabilitas, Pertumbuhan Perusahaan dan Opini Audit pada Pergantian Auditor". E-Jurnal Akuntansi Universitas Udayana, Vol. 8, No. 2.

Setiawan, I Made Agus dan Ni Ketut Lely Aryani M. 2014. "Pengaruh Corporate Social Responsibility, Auditor Opinion, Financial Distress, dan Size Terhadap Auditor Switching”. E-jumal Akuntansi Universitas Udayana. ISSN: 2302-8556.

Setyaningsih, Tika Dwi. 2014. "Analisis Faktor-faktor yang Memengaruhi Auditor Switching (Studi Empiris Perusahaan Manufaktur di Indonesia tahun 2006-2011)”. 
Sholihat, Walmi, R. Adri Satriawan Surya, dan Pipin Kurnia. 2014. "Analisis Faktor yang Mempengaruhi Perpindahan KAP di Indonesia (Studi Empiris pada Perusahaan Manufaktur yang Terdaftar di BEI Tahun 2010-2012”. JOM FEKOM, Vol. 01, No. 02.

Sianipar, Riduan Febri. 2015. "Faktor - Faktor Yang Mempengaruhi Auditor Switching Pada Perusahaan Manufaktur yang Terdaftar di Bei (Studi Empiris pada Perusahaan Manufaktur di BEI tahun 2011-2013)”. Jom FEKON Vol. 2 Nomor 2.

Sinarwati, Ni Kadek. 2010.” Mengapa Perusahaan Manufaktur yang Terdaftar di BEI Melakukan Pergantian Kantor Akuntan Publik?'. Simposium Nasional Akuntansi III Purwokerto, hal. 1-20.

Suparlan dan Andayani, Wuryan. 2010. “Analisis Empiris Pergantian Kantor Akuntan Publik Setelah Ada Kewajiban Rotasi Audit". Simposium Nasional Akuntansi XIII, Purwokerto, hal. 1-25.

Susanto, Oky Palasasari. 2015. "Faktor-Faktor yang Mempengaruhi Perusahaan Melakukan Auditor Switching (Studi Empiris pada Peusahaan Manufaktur yang Terdaftar di Bursa Efek Indonesia Tahun 2010-2014).

Wijayanti, Evi Dwi dan Indira Januarti. 2011. "Analisis Faktor-Faktor yang Mempengaruhi Perusahaan di Indonesia Melakukan Auditor Switching”. Simposium Nasional Akuntansi 14. Aceh. 